Web site: https://iournal.djas.uodiyala.edu.iq/

ISSN: 2073-9524 (Print)

https://dx.doi.org/10.52951/dasj.21130109

ISSN: 2310-8746 (Online)

\title{
Relationship of Scalp Color to Production Performance and Heat Tolerance of Holstein Cows
}

\author{
Bashar Adham Ahmad ${ }^{1}$ \\ Wasan Jassim Al-Khazraji ${ }^{2}$ \\ ${ }^{1}$ Department of Animal Production - College of Agriculture - University of Diyala - Iraq \\ ${ }^{2}$ Department of Animal Production - College of Agricultural Engineering Science - University of Baghdad - \\ Iraq
}

${ }^{1}$ Corresponding Author: basharadh83@gmail.com

\begin{abstract}
This study was conducted at Taj Al-Nahrain cows station in Al-Qadisiyah Governorate / Al-Diwaniyah district, which is $180 \mathrm{~km}$ from the center of Baghdad, and the duration of the experiment was extended from 1/9/2018 to 1/9/2019, the number of cows used in the experiment is 64 of the Holstein cows imported from Germany. To study the relationship between Scalp color and production performance and heat tolerance coefficient, 64 Holstein cows used in this experiment, cows divided into three groups according to the color of scalp cows as the ratio of spotting as $90 \%$ black, $50 \%$ black- $50 \%$ white and $90 \%$ white, The result of this study showed. The color of the scalp had a significant effect on the milk components, as the color of the scalp exceeded 50\% black 50\% white over the color of the scalp $90 \%$ black, and the color of the scalp $90 \%$ white, Was non-significant in other milk components, milk production, and heat tolerance coefficient.
\end{abstract}

Keywords: Scalp color, milk production, heat tolerance, Holstein cows.

\section{Introduction}

Living organisms vary in their ability to withstand heat stress, especially dairy cattle, as the sharp rise in ocean temperature causes a significant decrease in their production performance (Liu et al., 2010). Gaughan et al (2009) showed that the coefficient of heat tolerance is an important measure in high product strains if they can maintain excellent production level and good viability when exposed to heat stress conditions. Heat stress causes a set of symptoms on the animal, including high heart rates, reduced food intake, and decreased reproductive efficiency and productivity of cows (Kadokawa et al., 2012). The color of the scalp is one of the phenotypic traits that have potential effects on the ability of cows to resist heat stress caused by solar radiation, so the color of the scalp is directly related to the amount of heat absorbed from the solar radiation and has a relationship to the body temperature as white cows can reflect the sun rays more of its black counterparts, this reduces the heat gained and then reduces the negative effects of high temperature (Al-Abbasi, 2006). As for Al-Khuzai et al (2008), it was found in their study that there was a highly significant effect of the spotting rate on the length of the milk production season, and it was not significant in the length of the dry period.

\footnotetext{
${ }^{1}$ The research is quoted from the doctoral dissertation of the first researcher. Dates:
} 
It was also found that the measure of heat tolerance coefficient is related to the presence of the slick gene in cattle, which is characterized by its adaptability to hot environments compared to animals with dark color and long scalp (Gaughan et al., 2009). Al-Abbasi et al (2015) also indicated that there was a highly significant effect of spotting on the heat tolerance coefficient of white cows compared to mixed and black cows for June, July, August, September, and November. Lee et al (2016) in their study of 900 Holstein cows had no significant effect of spotting rate (black over 90\%, mixture 50:50, white over 90\%) on the length of the 305 days milk season and the productive life of the cow. The study aims to correlate the color of the scalp with the traits of milk production, milk components, and heat tolerance coefficient.

\section{Materials and methods}

\section{Ethic Approval}

The Scientific Ethical Committee in the College of Veterinary Medicine, University of Diyala was approved that the research proposal submitted.

Holstein cows were used in this experiment with black and white or white and red spotted in a very small percentage. The cows were divided according to the color of the scalp into three categories (90\% black 34 cows) (50\% black / 50\% white 24 cows) (90\% white 6 cows). Depending on the Phenotype of the spotting rate, the station includes semi-open pens for dairy cows, the length of one gable is $83 \mathrm{~m}$ and the width is $62 \mathrm{~m}$. It includes four barns and each barn contains 25 cows. The process of milking cows is done mechanically twice a day and includes a morning circuit and an evening circuit. The feeding system followed in the company is to give concentrated feed in the form of tablets (pellet) ready from the Turkish company (ipk), where The amount of feed consumed $10 \mathrm{~kg} / \mathrm{cow}$ producing milk is given with green fodder open to the extent of saturation when available in agricultural fields, while the hay is a free choice, silage. It is given to milk-producing cows when green fodder is not available from $4-5 \mathrm{~kg} / \mathrm{cow}$.

The process of measuring the respiratory rate was carried out by estimating the number of flank movements per minute for each cow twice a day in the morning and evening, as the morning breath is measured before the morning milking process at five in the morning when the day's temperature drops and in the evening the breath is measured before the evening milking process, at one o'clock in the afternoon, The high temperature of the day and over the course of four days of each of the studied seasons (summer, autumn, and winter), and this process was carried out in two ways by counting with the naked eye, and the method of counting using a camera on the loin area, and after recording the video clip, in which the number of times of breathing is recorded. The process of measuring the temperature of the body was carried out with a mercury thermometer by inserting the thermometer into the opening of the rectum, taking into account the position of the thermometer in an oblique manner to ensure that the thermometer touches the rectal wall from the inside to obtain an accurate reading, as it takes the reading after a minute has passed. The body temperature of each cow was measured twice a day in the morning and evening. The temperature is measured before the morning milking process at five in the morning when the day's temperature is lower, and in the evening the temperature is measured before the evening milking process, that is, at one o'clock in the afternoon, that is, when the day's temperature rises for four days. From each of the studied seasons (summer, autumn, and winter).

The Heat Tolerance Coefficient (HTC) was calculated according to the following equation (Benezra 1954).

$\mathrm{HTC}=\mathrm{RR} / 23+\mathrm{TR} / 38.3$ 
HTC represents the thermal endurance coefficient

$\mathrm{RR}$ is the respiratory rate of a cow

TR rectal temperature of the cow

23 The normal respiratory rate for a cow under normal conditions

38.33 represent the ideal rectal temperature for cows

The temperature and humidity were measured twice a day at six in the morning and two in the afternoon using a mercury thermometer and Hygrothermograph installed in the bar, which contains two gauges, one of which is to measure the temperature (Celsius) and the other to measure the relative humidity, and the measurement was carried out in July, October and December, within two days. The index of temperature and humidity was calculated according to the equation mentioned by Mader et al (2006) for each month.

$\mathrm{THI}=(0.8 \times \mathrm{Tdb})+((\mathrm{RH} / 100) \times(\mathrm{Tdb}-14.4)]+46.4$

As: THI: index of temperature and Humidity

RH: represents relative humidity

Tdb: dry thermometer temperature

$0.8,14.4$, and 46.4 represent constants

The data on milk production was collected from the station's records, as the weekly milk production for the morning and evening is recorded by the station. As for the milk components, $10 \mathrm{ml}$ of milk from the morning milking was withdrawn from each cow with plastic tubes for three periods (July, October, and December) and the components were analyzed at Abu Ghraib Dairy Company Division of Milk Analyzer.

The average production last three months

Perseverance in production $(\%)=$

The average production of the first three months

The data were analyzed statistically using the SAS (Statistical Analysis System) (2010) method to study the effect of scalp color on the treats of milk production, its components, and heat tolerance coefficient. Significant differences between the averages were tested using the polynomial test Duncan (1955).

$Y i j=\mu+C i+$ eijk

$Y i j=$ the viewing value $i$ of the scalp color $j$

$\mu=$ the general mean of the studied trait

$\mathrm{Ci}=$ the effect of the scalp color, as the value of $\mathrm{i}=3$ (90\% black, 50\% black / 50\% white, $90 \%$ black)

eijk = the experimental error of a normal and independent distribution with a mean of zero and an equal variance of $2 \sigma$.

\section{Results and discussion}

It is evident from (Table 1) that there was no significant effect of scalp color on total milk production, peak production, perseverance on production, length of production season, and this result is in agreement with King et.al. (1988) and with Rundle (2013) and with Lee et al. (2016) and does not agree with Becerril et al ( 1993), Al-Khuzai et. al (2008); Al-Douri (2002). 
Table 1. The effect of scalp color on milk production

\begin{tabular}{|c|c|c|c|c|c|}
\hline scalp color & $\begin{array}{c}\text { NO. } \\
64\end{array}$ & $\begin{array}{c}\text { total milk } \\
\text { production }\end{array}$ & $\begin{array}{c}\text { peak } \\
\text { production }\end{array}$ & $\begin{array}{c}\text { perseverance on } \\
\text { production/\% }\end{array}$ & $\begin{array}{c}\text { length of the } \\
\text { production } \\
\text { season }\end{array}$ \\
\hline \hline $90 \%$ black & 34 & $\begin{array}{c}4212.04 \pm \\
169.51\end{array}$ & $\begin{array}{c}341.47 \\
\pm 14.38\end{array}$ & $1.51 \pm 0.08$ & $301.76 \pm 4.89$ \\
\hline \hline $\begin{array}{c}50 \% \text { black / } \\
50 \% \text { white }\end{array}$ & 24 & $\begin{array}{c}4040.67 \\
\pm 231.15\end{array}$ & $\begin{array}{c}386.25 \pm \\
25.62\end{array}$ & $1.20 \pm 0.12$ & $293.75 \pm 8.27$ \\
\hline \hline $90 \%$ white & 6 & $\begin{array}{c}4197.57 \\
\pm 481.33\end{array}$ & $\begin{array}{c}375.0 \\
\pm 46.95\end{array}$ & $1.46 \pm 0.24$ & $290.0 \pm 14.82$ \\
\hline
\end{tabular}

It can be seen from Table (2) that the color of the scalp has a significant effect on the components of milk, as the cows with the color of the scalp (50\% black / 50\% white) on the cows with the scalp color $90 \%$ black and the scalp color $90 \%$ white significantly in non-fat solids (7.78, 7.33 and 6.89\%), respectively, as for the density, the scalp color is $50 \%$ black / $50 \%$ white, and the scalp color is $90 \%$ black over the scalp color $90 \%$ white significantly (28.18, 26.85 and $23.79 \mathrm{~g} / \mathrm{cm} 3)$, respectively. Scalp color (50\% black / 50\% white) on cows with a scalp color of $90 \%$ black and cows with a scalp color $90 \%$ white in the ratio of protein and reached $(2.81,2.65$, and $2.47 \%)$, respectively, and in the ratio of lactose (4.26, 4.02 and $3.77 \%$ ) Respectively, and this result is similar to what Jassim (2013) found.

Table 2. The effect of scalp color on components of milk \%

\begin{tabular}{|c|c|c|c|c|c|c|}
\hline scalp color & $\begin{array}{c}\text { NO. } \\
64\end{array}$ & fat & $\begin{array}{c}\text { non-fat } \\
\text { solids }\end{array}$ & density & protein & lactose \\
\hline $90 \%$ black & 34 & $3.25 \pm 0.20$ & $\begin{array}{c}7.33 \pm 0.12 \\
\mathrm{ab}\end{array}$ & $\begin{array}{c}26.85 \pm 0.54 \\
\mathrm{ab}\end{array}$ & $\begin{array}{c}2.65 \pm 0.04 \\
\mathrm{ab}\end{array}$ & $\begin{array}{c}4.02 \pm 0.06 \\
\mathrm{ab}\end{array}$ \\
\hline $\begin{array}{c}50 \% \text { black / } \\
50 \% \text { white }\end{array}$ & 24 & $3.42 \pm 0.16$ & $\begin{array}{c}7.78 \pm 0.13 \\
\mathrm{a}\end{array}$ & $\begin{array}{c}28.18 \pm 0.46 \\
\mathrm{a}\end{array}$ & $\begin{array}{c}2.81 \pm 0.04 \\
\mathrm{a}\end{array}$ & $\begin{array}{c}4.26 \pm 0.06 \\
\mathrm{a}\end{array}$ \\
\hline $90 \%$ white & 6 & $3.55 \pm$ & $\begin{array}{c}6.89 \pm 0.37 \\
\mathrm{~b}\end{array}$ & $\begin{array}{c}23.79 \pm 2.47 \\
\mathrm{~b}\end{array}$ & $\begin{array}{c}2.47 \pm 0.14 \\
\mathrm{~b}\end{array}$ & $\begin{array}{c}3.77 \pm 0.21 \\
\mathrm{~b}\end{array}$ \\
\hline
\end{tabular}

Different letters within the same column indicate a significant difference at the level $(\mathrm{P} \leq 0.05)$.

Table (3) shows the non-significant effect of scalp color (90\% black and 50\% black / 50\% white and $90 \%$ white) on heat tolerance coefficient of summer, autumn, and winter and general tolerance coefficient and this result is not compatible with Al-Abbasi et. al. (2015). was found that white cows were significantly superior to spotted cows and black cows in the summer and autumn months. 
Table 3. The effect of scalp color on heat tolerance coefficient

\begin{tabular}{|c|c|c|c|c|c|}
\hline scalp color & $\begin{array}{c}\text { NO. } \\
64\end{array}$ & $\begin{array}{c}\text { heat tolerance } \\
\text { coefficient of } \\
\text { summer }\end{array}$ & $\begin{array}{c}\text { heat tolerance } \\
\text { coefficient of } \\
\text { autumn }\end{array}$ & $\begin{array}{c}\text { heat tolerance } \\
\text { coefficient of } \\
\text { winter }\end{array}$ & $\begin{array}{c}\text { heat tolerance } \\
\text { coefficient of } \\
\text { general }\end{array}$ \\
\hline $90 \%$ black & 34 & $2.71 \pm 0.02$ & $2.23 \pm 0.02$ & $1.92 \pm 0.01$ & $2.29 \pm 0.01$ \\
\hline $\begin{array}{c}50 \% \text { black / } \\
50 \% \text { white }\end{array}$ & 24 & $2.67 \pm 0.04$ & $2.30 \pm 0.02$ & $1.93 \pm 0.01$ & $2.30 \pm 0.01$ \\
\hline $90 \%$ white & 6 & $2.67 \pm 0.07$ & $2.32 \pm 0.07$ & $1.91 \pm 0.03$ & $2.30 \pm 0.04$ \\
\hline
\end{tabular}

In light of the study, the barn temperature was recorded in the morning and evening for July, October and December only (Table 4) for summer, autumn and winter, and the morning temperature was $(27.55,16.9$ and 10.9) Degree respectively, and the evening temperature (43.15, 26.45 and 16.5) Degree, respectively. As for the relative humidity, it varied between morning and evening and between the months of the study, as the relative humidity was recorded in the barn in the morning $(24,61.5$, and $81.5 \%)$ and the evening $(10,51.5$, and $60 \%$ ) respectively.

The temperature and humidity index was calculated from registering the temperature and relative humidity of the barn, as the temperature and humidity index is a guide to knowing whether the cows are in a state of heat stress and the normal temperature and humidity index is 72 , and any rise from this index is stress and in different stages.

As for the body temperature, it was measured for each cow rectally and from Table (4) it is found that the rectal temperature in July in the morning and evening (37.56 and 37.95) $\mathrm{m}$, respectively, and in December in the morning and evening (34.69 and 35.09), respectively, and this result close with Xiong et al. (2013); Bhat et al. (2016).

The thermal endurance coefficient was calculated depending on the rate of respiration and the rectal temperature, as it was found that there was a difference between the thermal endurance coefficient for July and December in the morning and evening, which amounted to (2.67 and 2.74) (1.84 and 1.99), respectively, and this is close to what Al-Abbasi and Al-Douri (2012) found. Also similar to Arya (2014).

Table 4. Index of temperature, humidity, and some temperature parameters in different months

\begin{tabular}{|c|c|c|c|c|}
\hline \multirow{2}{*}{\multicolumn{2}{|c|}{$\begin{array}{ll} & \text { month } \\
\text { parameters } & \end{array}$}} & \multirow{3}{*}{$\begin{array}{c}\text { July } \\
27.55\end{array}$} & \multirow{3}{*}{$\begin{array}{c}\text { October } \\
16.9\end{array}$} & \multirow{3}{*}{$\begin{array}{c}\text { December } \\
10.9\end{array}$} \\
\hline & & & & \\
\hline \multirow{2}{*}{ Temperature / m } & morning & & & \\
\hline & Evening & 43.15 & 26.45 & 16.5 \\
\hline \multirow{2}{*}{ Relative humidity\% } & morning & 24 & 61.5 & 81.5 \\
\hline & Evening & 10 & 51.5 & 60 \\
\hline \multirow{2}{*}{$\begin{array}{l}\text { Index Heat and } \\
\text { Humidity THI }\end{array}$} & morning & 72.28 & 61.43 & 51.75 \\
\hline & Evening & 83.79 & 73.74 & 61.36 \\
\hline \multirow{2}{*}{$\begin{array}{l}\text { Respiratory rate / } \\
\text { minute breath }\end{array}$} & morning & 37.73 & 25.46 & 21.78 \\
\hline & Evening & 40.37 & 34.68 & 25.03 \\
\hline \multirow{2}{*}{$\begin{array}{l}\text { Average rectal } \\
\text { temperature / m }\end{array}$} & morning & 37.56 & 36.21 & 34.69 \\
\hline & Evening & 37.95 & 37.23 & 35.09 \\
\hline \multirow{2}{*}{$\begin{array}{l}\text { Heat Tolerance } \\
\text { Coefficient } \%\end{array}$} & morning & 2.67 & 2.04 & 1.84 \\
\hline & Evening & 2.74 & 2.47 & 1.99 \\
\hline
\end{tabular}




\section{Conclusions}

We conclude from the results of the research that the cows used in the study were raised in semi-open pens and in hot climates that are exposed to sunlight, so the color of the scalp had a direct effect on the characteristics of the milk as the cows with the color of the scalp (50\% black / 50\% white) significantly in non-fat solids, density, the ratio of protein, the ratio of lactose.

\section{Conflict of interest}

The authors declare that they have no conflict interests

\section{Acknowledgment}

Thanks to the supervisor Dr. Wassan and the staff of Taj Al-Nahrain Company and to the staff of the Animal Production Department, College of Agricultural Engineering Sciences / University of Baghdad, for their assistance in carrying out this research.

\section{Reference}

Al- Douri, Z. S. A. 2002. The effect of heat stress and scalp color (black and red) on some aspects of the performance of Holstein-Friesian cows in Iraq, $\mathrm{PhD}$ thesis, College of Agriculture, University of Baghdad.

Al-Abbasi, I. G. Abdel-R. 2006. Genetic evaluation of Friesian cows in Ishaqi station depending on milk production. Master Thesis . faculty of Agriculture . Tikrit University.

Al-Abbasi, I. G. and, Z. S. Al-Douri. 2012. The temperature and humidity index is an indication of a decrease in the productive and physiological performance of Friesian cows due to heat stress. Tikrit Journal of Agricultural Sciences. 12 (4): 29-34.

Al-Abbasi, I. G. Al-Anbari, N. N. Al-Douri, Z. Shaker. 2015. The effect of the level of milk production and some factors on the heat tolerance coefficient of Friesian cows in hot climates. Al Furat Journal of Agricultural Sciences. 7 (2): 128--134.

Al-Khuzai, H. M., A. J. H. Al-Hamidawi, S. A. M. Al-Jannah . 2008. The effect of genetic and non-genetic factors on productive traits of Friesian cows in central Iraq. University of Karbala Scientific Journal. 6 (2): 222-225.

Arya, A . 2014 . molecular characterization and SNP identification of heat shock protein 27 gene in murrah buffalo . master of veterinary science . national dairy research institute, karnal .

Becerril, C.M., Wilcox, C.J., Lawlor, T.J., Wiggans, G.R. and Webb, D.W. 1993. Effect of percentage of white coat color on Holstein production and reproduction in a subtropical environment. J. Dairy Sci. 76:2286-2291.

Benezra, M.V. 1954. Anew index for measuring the adaptability of cattl to tropical conditions.J.AANIM.sci.13:1015.

Bhat, S., Kumar, P., Kashyap, N., Deshmukh, B., Dige, M. S., Bhushan, B.,and Singh, G. 2016. Effect of heat shock protein 70 polymorphism on thermotolerance in Tharparkar cattle. Veterinary world, 9(2), 113.

Duncan, D.D. 1955. Multiple range and multiple F-test Biometrics , 11: 1-42. 
Gaughan, J.B., Mader, T.L., Holt,S.M.,Sullivan,M.L. and Hahn,G.L. 2009. Assessing the heat tolerance of 17 beef cattlegenotypes. International Journal of Biomtechnology. 131170.

Jassim, N. H. 2013. Predict the productive and physiological performance of the Iraqi buffalo (Bubalus bubalis) based on the heat tolerance coefficient and the index of temperature and humidity. Master Thesis . faculty of Agriculture . Baghdad University .

Kadokawa, H., Sakatani, M. and Hansen, P.J. 2012. Perspective on improvement of reproduction in cattle during heat stress in a future Japan. Anim. Sci. J. 83(6):439-445.

King, V.L., Denise, S.K., Armstrong, D.V., Torabi, M. and Wiersma, F. 1988. Effects of a hot climates on the performance of first lactation Holstein cows grouped by coat color. $J$. Dairy Sci.71:1093-1096.

Lee, C. N., Baek, K.S. and Parkhurst, A. 2016 . The impact of hair coat color on longevity of Holstein cows in the tropics . Journal of Animal Science and Technology. 41-58 .

Liu, Y.X., Zhou, X., Li, D.Q., Cui, Q.W. and Wang. G.L. 2010. Association of ATP1A1 gene polymorphism with heat tolerance traits in dairy cattle. Genetics and Molecular Research.9:891-896.

Mader, T. L., Davis, M. S. and Brown-Brandl,T. 2006. Environmental factors influencing heat stress in feedlot cattle. J. Anim. Sci. 84:712-719.

Rundle,V .2013. Effects of hot climate on the performance of lactating Holstein cows grouped by percentage of white coat color. A MS thesis, the Universityof Arizona.

SAS. 2010. SAS/STAT User's Guide for Personal Computers . Release 9.1 SAS Institute Inc. , Cary, N. C. , USA .

Xiong, Q.I., Chai, Jin., Haiqian, X., Wengong, L., Huang, T., Yang, L. Xiaojun, S., Nian,Z.,Xiaofeng,L.,Siwen, J. and Mingxin, C. 2013. Association analysis of HSP70A1A haplotypes with heat tolerance in Chinese Holstein cattle. Cell Stress and Chaperones. 18 (6): 711-718. 